\title{
EHEPГETИKA
}

УДК 536.24:533.6.011

DOI https://doi.org/10.32838/2663-5941/2021.2-2/06

\section{Баранюк О.В.}

Національний технічний університет України

«Київський політехнічний інститут імені Ігоря Сікорського»

\section{Воробйов М.В.}

Національний технічний університет України

«Київський політехнічний інститут імені Ігоря Сікорського»

\section{МОДЕЛЮВАННЯ ТЕЧІЇ І ТЕПЛООБМІНУ В ТРУБАХ ІЗ ТУРБУЛІЗАТОРАМИ У ВИГЛЯДІ СКРУЧЕНИХ СТРІЧОК}

У роботі проведено чисельне дослідження і побудова чисельної моделі течії в ииліндричних трубах з інтенсифікатором теплообміну у вигляді скрученої стрічки за допомогою ANSYS-Fluent. Метою роботи є вивчення механізму інтенсифікації теплообміну в умовах складної внутрішньої течії за допомогою CFD-методів. Для досягнення поставленої мети розроблена $C F D$-модель течії і теплообміну в ичліндричних трубах з діаметрами 18, 28 та 36 мм, в середині яких розмімувалась скручена стрічка, ступінь закрутки якої змінювався в діапазоні від до 3 до 9. Досліджувався теплообмін при турбулентній течії повітря з наступними параметрами на вході в трубу: середня температура $T_{\infty}=19,3{ }^{\circ}$, тиск $P_{\infty}=0,1$ МПа, ступінь турбулентності Tu${ }_{\infty}=0,1 \%$, профіль швидкості - рівномірний. На стінці задавалися граничні умови виду $T_{w}=$ const. Числа подібності розраховувалися за середньою швидкістю повітря, віднесеною до круглого поперечного перерізу труби з внутрішнім діаметром $d$, який служив $i$ визначальним розміром. Як визначальна температура бралася середня температура потоку повітря 8 трубі. Дослідження проводилися в діапазоні чисел Рейнольдса Re $=(1,5 \ldots 4,4) \cdot 10^{4}$.

Попередньо проведена валідаиія методики розрахунку на ициліндричній трубі свідчить, щцо модель, розроблена в середовищі ANSYS-Fluent, коректно відображсає сутність прочесів течії і теплообміну в циліндричній трубі і може використовуватися для дослідження відривного проиесу в трубах з турбулізаторами. Для моделювання використовувалась академічна лічензія програмного комплексу ANSYS Student, яка є (з 2015 року) абсолютно безкоштовною і призначена для вирішення ознайомлювальних $i$ освітніх задач в академічному середовищі.

Результати CFD-моделювання дозволили визначити, щчо інтенсифікація тепловіддачі досягається за рахунок збільшення пристінної швидкості потоку і виникнення вторинних течій, щьо виникають під дією відиентрових сил і підсилюють теплообмін між ядром потоку і примежовим шаром, який розвивається на поверхнях теплообміну. На жаль, не отримано випереджаючого росту теплообміну над ростом гідравлічного опору. Гідравлічний опір труби зі скрученою стрічкою зростає (у порівнянні з чиліндричною трубою) в середньому у 1,35-1,55 рази. Це може бути пов'язано зі збільшенням поверхні тертя і додатковими витратами енергії на створення обертального руху теплоносія і утворення вторинних поперечних течій.

Ключові слова: вимушена конвекція, інтенсифікачія, скручена стрічка, моделювання, завихреність, вторинні течії.

Постановка проблеми. Представлена робота присвячена аналізу структури течії в трубах із стрічковим завихорювачем. Стрічкові й інші завихорювачі потоку ефективно застосовуються в технологічних і промислових котлах з димогарними трубами під час їх роботи на відносно чистих гарячих газах (спалювання газу, мазуту). Відомо, що стрічковий завихорювач при кроці закрутки 0,712 м, ширині стрічки 66 мм і товщині 1,4 мм збільшує тепловіддачу на $65 \%$, а гідравлічний опір - на $160 \%$ порівняно з гладкою трубою за інших рівних умов. Такі завихорювачі, інтенсифікуючи теплообмін, призводять до істотної економії витрати палива на підігрів рідини в паровому котлі [1].

Беззаперечно, що структура закрученого потоку дуже складна. Рух рідини складається 
3 поздовжнього і обертального і має гвинтоподібний характер, одночасно в поперечному перерізі труби може виникати замкнута вихрова вторинна течія. Визначити і зрозуміти механізм інтенсифікації теплообміну можливо тільки за допомогою новітніх PIV-методів [2] та більш простим і дешевшим методом чисельного моделювання [3].

Аналіз останніх досліджень і публікацій. Дослідження і впровадження в промисловість різних методів інтенсифікації теплообміну ніколи не втратять своєї актуальності. На цей час інтенсифікація конвективного теплообміну є однією з перспективних і складних задач, яка спрямована на зменшення маси теплоенергетичного обладнання i/або значного підвищення його ефективності. Традиційно вважається, що ця задача найбільш актуальна для теплоносіїв, яким притаманні високі значення чисел Рейнольдса. Практично всі основні монографії на тему інтенсифікації конвективного теплообміну [4-8], що можна знайти в доступній літературі, присвячені аналізу течії в умовах високорейнольдсових течій і високих числах Рейнольдса.

Над дослідженням інтенсифікації теплообміну в трубі за допомогою стрічкових турбулізаторів працювали такі провідні вчені, як В.К. Щукін, А. Берглс, Сперроу, Р.3. Алімов, Г.А. Дрейцер, Б.В. Дзюбенко, В.М. Івлев, А.А. Халатов, Ю.М. Бродов та інші. Їхні роботи допомогли визначити, що при ламінарному і перехідному режимах стрічкові завихорювачі дозволяють збільшити тепловіддачу в кілька разів за помірного зростання втрат енергії на прокачування теплоносія. В цьому режимі течії завихорювачі особливо ефективні. У турбулентному режимі під час використання стрічкових завихрителей досягається збільшення тепловіддачі в 1,5-2 рази.

Зниження ефективності завихрювачів під час зростання числа Рейнольдса пояснюється тим, що розглянуті інтенсифікаторами теплообміну впливають на весь потік, а не тільки на пристінну область. Турбулентність ядра течії за досить великих чисел Рейнольдса настільки висока, що додаткова турбулізація потоку за допомогою завихрювача стає малоефективною i енергетично недоцільною. Практично цікавий діапазон відносних кроків закрутки стрічки $-2 \ldots 15$. За менших кроків різко зростає опір, за великих - значно знижується рівень інтенсифікації теплообміну. В рекомендованому діапазоні відносних кроків тепловіддача зростає приблизно пропорційно збільшенню гідравлічного опору.
Роботи авторів [9] свідчать, що стрічкові і шнекові завихорювачі, встановлені на вході в трубу на короткому вхідному ділянці, інтенсифікують теплообмін у кілька разів, а на досить видовженому ділянці труби (50-60 діаметрів і більше) забезпечують підвищення тепловіддачі в 1,5-2,5 рази. Тому авторами статті прийнято рішення дослідити вплив турбулізатора, що встановлений в початковій ділянці труби для найбільш вірогідного в енергетиці режиму течії - перехідного.

Постановка завдання. Дослідниками [10] накопичено великий експериментальний матеріал по теплообміну в трубах із стрічковими завихорювачами, яким присвячено достатню кількість монографій. Проте слід зазначити, що в останнє десятиліття стрімкий розвиток програмних комплексів, призначених для обчислення характеристик потокових процесів із широкими можливостями візуалізації розрахункових даних (наприклад ANSYS), призвів до того, що жодного фундаментального наукового дослідження без розділів, присвячених моделюванню, не виконується. Роботи, присвячені моделюванню теплообміну в гладкій трубі з стрічковим завихорювачем, $\epsilon$, проте їх значно менше і вони не настільки якісно виконані, як експериментальні роботи. Тому вирішення відомих задач на новому рівні $є$ також актуальним завданням.

Мета статті - дослідити структуру потоку i визначити середні характеристики теплообміну в гладкій трубі із інтенсифікатором у вигляді скрученої стрічки за допомогою відомого пакету програм CFD-моделювання ANSYS-Fluent, що дозволяє після попередньої верифікації з експериментальними даними взятими 3 робіт інших авторів, розширити діапазони режимних та геометричних параметрів дослідних інтенсифікаторів.

Методи, об'єкт та предмет дослідження. Метод дослідження - чисельний, за допомогою академічної ліцензії програмного комплексу ANSYS Student. Ця ліцензія $\epsilon$ абсолютно безкоштовною (з 2015 року) і призначена для вирішення ознайомлювальних і освітніх задач в академічному середовищі.

Об'єкт дослідження - процеси, що протікають під час течії і теплообміну в гладкій циліндричній трубі з інтенсифікатором теплообміну у вигляді скрученої стрічки.

Предмет дослідження - циліндричні труби, внутрішній діаметр $d$, яких становив 18, 28, і 36 мм. Довжина труб $L$ і товщина стрічки $\delta$ не змінювались і становили відповідно 300 і 1 мм. Ступінь закрутки $s / d$ змінювався в діапазоні від до 3 до 9. 
Виклад основного матеріалу дослідження. Розробка чисельної CFD-моделі включає в себе процес комп'ютерної інтерпретації таких її складників, як геометричні, граничні умови і фізичні властивості досліджуваного об'єкта. Процедура моделювання передбачає дискретизацію досліджуваної геометрії за допомогою розрахункових сіток, що дозволяють представити фізико-математичний опис початкового ділянки, яке базується на чисельному рішенні усереднених по Рейнольдсу рівнянь Нав'є-Стокса, замкнутих за допомогою моделі турбулентності на основі концепції вихрової в'язкості типу $k$ - $\varepsilon$ realizable [11]. Використання в роботі цієї моделі в першу чергу продиктовано тим, що ця модель запропонувала більш обгрунтоване формулювання рівняння переносу швидкості дисипації, оскільки вона отримана з рівняння переносу середньої завихрюваності. А також під час застосування цієї моделі неможливо отримати негативних значень для $\overline{u_{j}^{\prime 2}}$ значних деформаціях поля середньої швидкості. Автори [11] рекомендують використання цієї моделі для течій з великою кривизною ліній току і закручуванням течії. Закручування потоку в цій задачі може відбуватись внаслідок гідродинамічної взаємодії між ядром потоку і примежовим шаром, який розвивається на поверхнях теплообміну (поверхні скрученої стрічки і криволінійної поверхні труби).

Керуючі рівняння математичної моделі турбулентної течії, що має місце в цій задачі, і рівняння стандартної моделі турбулентності приведені в [12] і в інших підручниках з чисельних методів в гідродинаміці.

У цій публікації розглядався теплообмін в умовах перехідного режиму течії повітря 3 наступними параметрами на вході в трубу: $T_{\infty}=19,3{ }^{\circ} \mathrm{C}$, тиск $P_{\infty}=0,1$ МПа, ступінь турбулентності
$T u_{\infty}=0,1 \%$, профіль швидкості - рівномірний. На зовнішній циліндричній стінці задавалися граничні умови першого роду виду з огляду на використання як базової відомої експериментальної залежності А.С. Сукомєла [13], отриманої за аналогічних граничних умов.

Теплофізичні властивості повітря задавались у вигляді поліноміальних залежностей від температури. Числа подібності розраховувалися за середньою швидкістю повітря, віднесеною до круглого поперечного перерізу труби з внутрішнім діаметром $d$, який служив і визначальним розміром. Як визначальна температура бралася середня температура потоку повітря в трубі. Дослідження проводилися в діапазоні чисел Рейнольдса $\operatorname{Re}=(1,5 \ldots 4,4) \cdot 10^{4}$.

Чисельне рішення системи базових і модельних рівнянь грунтувалося на неявному скінченооб'ємному підході 3 використанням процедури корекції тиску SIMPLE (Semi-Implicit Method for Pressure Linked Equations). Це найпоширенiший і найбільш стійкий 3 алгоритмів числового рішення рівнянь Нав'є-Стокса. Для інтерполяції на грані контрольних об'ємів термодинамічних параметрів, що обчислювались в їх центрах використовувались алгоритми Least Squares Cell Based та Second-Order, що призначувались для моделювання потоків, в яких спостерігаються ефекти стискаємості.

Розрахункова область покривалася нерівномірною, зі згущенням до твердотільних стінок моделі тетраедричних сіткою. Тривимірна розрахункова сітка представлена на рис. 1. Максимальна кількість чарунок, вибрана для дискретизації розрахункової області складала 4 млн. Для всіх рівнянь системи був обраний критерій збіжності рішення, рівний $10^{-5}$.

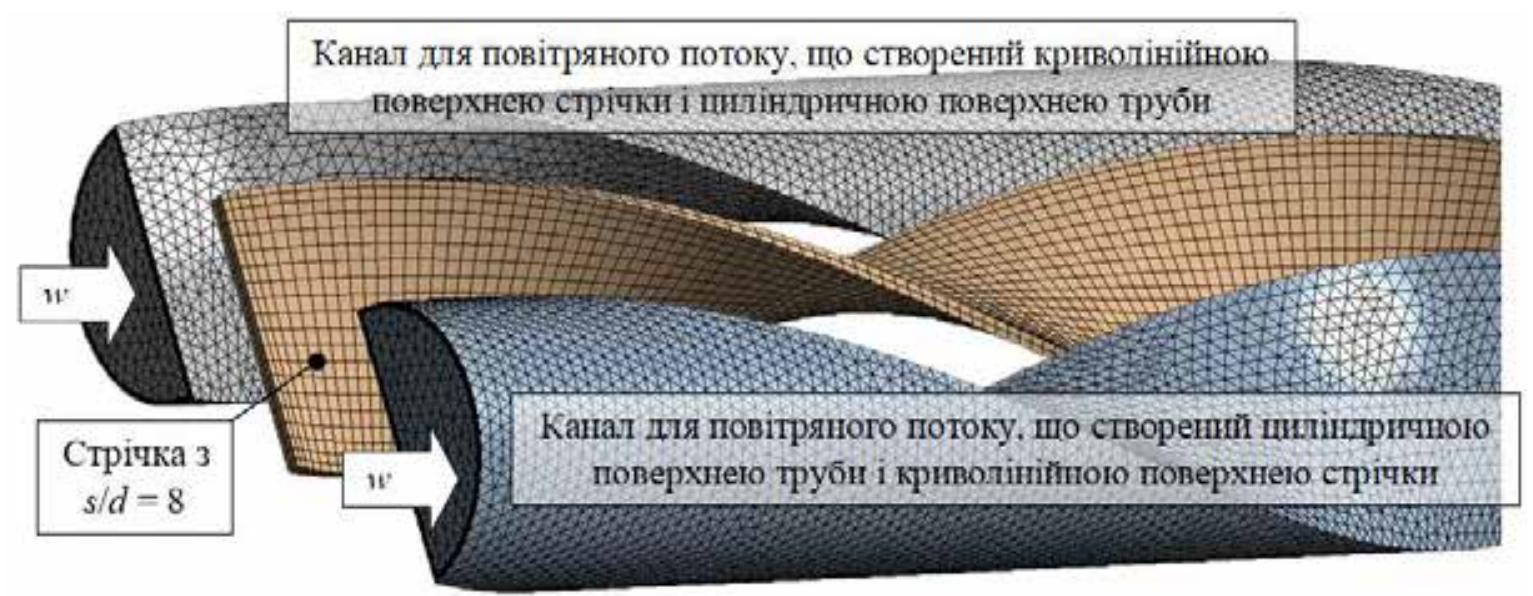

Рис. 1. Скінченно-елементна сітка моделі $3 s / d=8$ з $d=18$ мм 
Валідація моделі і адекватність прийнятих методик були протестовані на апробованій задачі теплообміну й течії на початковій ділянці гладкої циліндричної труби, шляхом зіставлення обчислених значень середніх коефіцієнтів тепловіддачі і коефіцієнтів гідравлічного опору в розглянутому діапазоні чисел Рейнольдса з відомими експериментальними залежностями [8]. Порівняльний аналіз результатів розрахунку CFD-моделей для гладкої циліндричної труби (результати CFDмоделювання представлені суцільними лініями) по теплообміну (рис. 2, а) і опору (рис. 2, б) свідчить, що максимальне відхилення даних не перевищує 4\% в порівнянні з відомими залежностями [8] та даними роботи [14], що свідчить про коректність використовуваного під час моделювання підходу загалом.

Аналіз даних в доступній літературі свідчить, що в трубах зі стрічковими завихрювачами можливі ламінарна, ламінарна з макровихрами і турбулентна течії. Тому для верифікації результатів CFD-моделювання, автори використали критеріальні залежності для визначення середнього теплообміну і опору, що отримані в роботі [8] для ламінарного та турбулентного режимів течії в трубах з стрічковими вставками.

Для ламінарної течії:

$$
\begin{gathered}
\overline{\mathrm{Nu}_{f}^{*}}=\frac{\alpha d_{\text {ек }}}{\lambda}=0,3 \operatorname{Re}_{f}^{* 0,33} \cdot \operatorname{Dn}_{f}^{* 0,27} \cdot \operatorname{Pr}_{f}^{0,43} \\
\xi=\frac{6,34}{\operatorname{Re}_{e}^{0,47}}\left(\frac{d}{D}\right)^{0,26}+\frac{25,6}{R e_{e}}
\end{gathered}
$$

де $\mathrm{Nu}_{e}, \mathrm{Re}_{e}$ - числа Нусельта і Рейнольдса, в яких характерним розміром $\epsilon$ еквівалентний діаметр каналу; $d / D$ - відношення діаметру труби до діаметру кривизни гвинтової лінії. Рівняння отримано в діапазоні числа Діна:

$$
\operatorname{Dn}=\operatorname{Re} \sqrt{2 s / d}, s / d=2,5 \ldots 11 .
$$

Фізичні властивості взяті при температурі потоку.

Середній діаметр кривизни гвинтової лінії, утворений стінкою труби і стрічковим завихрювачем, залежить від кроку стрічкового завихрювача і визначається за допомогою залежності:

$$
\frac{D}{d}=\frac{1}{2}-\frac{8}{\pi^{2}}\left(\frac{s}{d}\right)^{2}
$$

Для характеристики закрученої течії використовувався так званий [1] «коефіцієнт закрутки»: $k=\pi D / s-$ відношення тангенціального та осьового складників швидкості закрученого потоку у стінки. За ефективну швидкість потоку приймалась швидкість поблизу внутрішньої поверхні труби: $w_{e}=w\left(1+k^{2}\right)^{0,5}$.

Для турбулентної течії:

$$
\begin{aligned}
\overline{\mathrm{Nu}_{f}^{*}} & =\frac{\alpha d_{\text {екB}}}{\lambda}=0,079 \cdot \varepsilon_{t} \cdot \operatorname{Re}_{f}^{* 0,74} \cdot\left(\frac{d}{D}\right)^{0,11} \cdot \operatorname{Pr}_{f}^{0,43} \\
\xi & =0,705 \cdot \operatorname{Re}_{e}^{-0,28}\left(\frac{d}{D}\right)^{0,09}+0,009\left(\frac{d}{D}\right)^{0,09}
\end{aligned}
$$

де $\varepsilon_{t}-$ поправка на довжину початкової ділянки. Визначалась за формулою:

$$
\varepsilon_{t}=1+\frac{2}{L / d},
$$

де $L$-довжина труби.

Результат верифікації для двох граничних діаметрів труб, які використовувались під час моделювання - 18 і 36 мм для ступеню закрутки потоку $s / d=2$ і 8 представлений на рис. 3. Аналіз

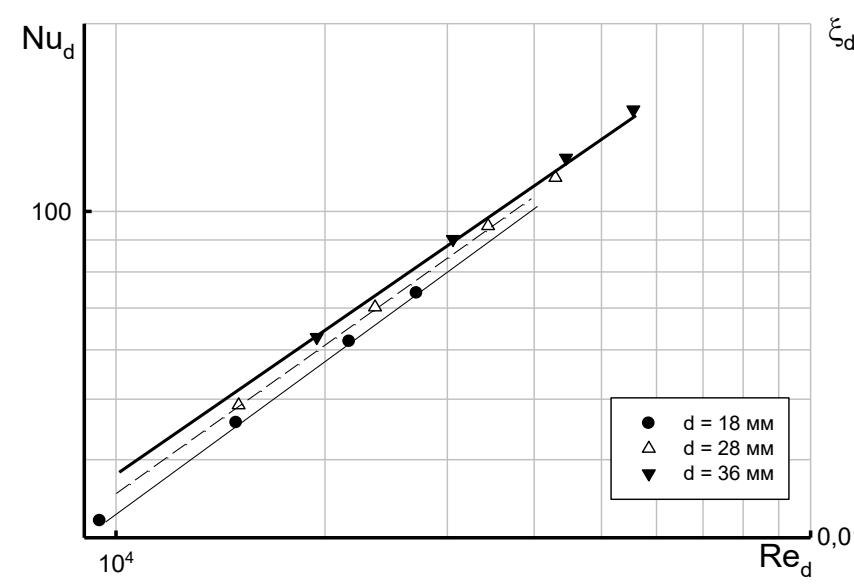

a)

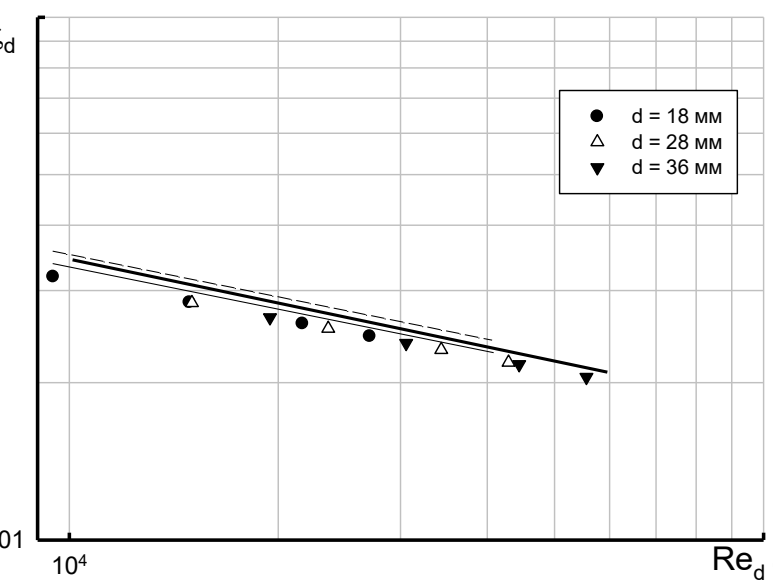

б)

Рис. 2. Залежність чисел Нусельта від чисел Рейнольдса (а) та коефіціснта опору (б) для тестової задачі течії в гладкій циліндричній трубі 


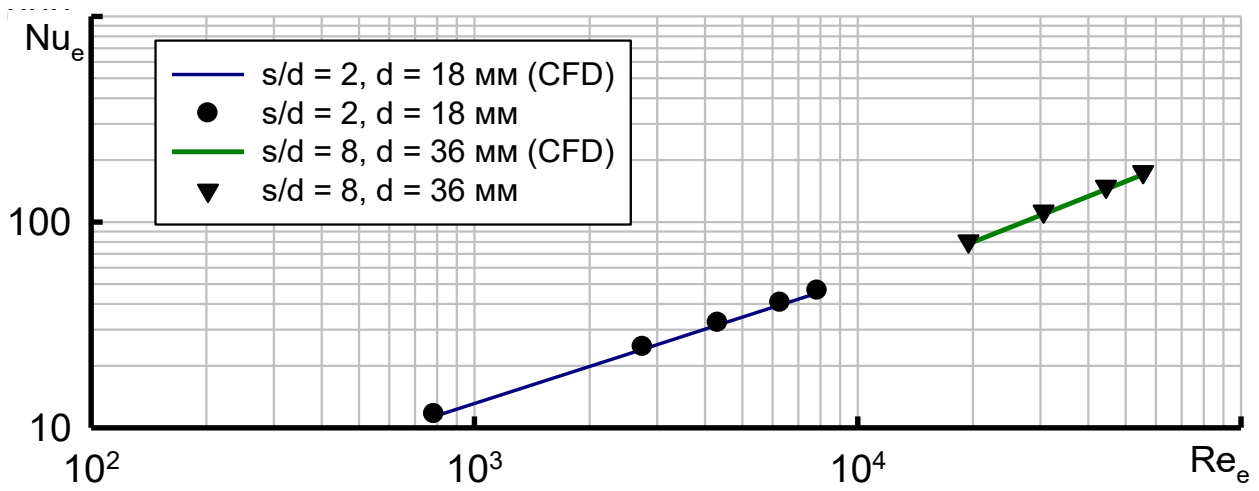

a)

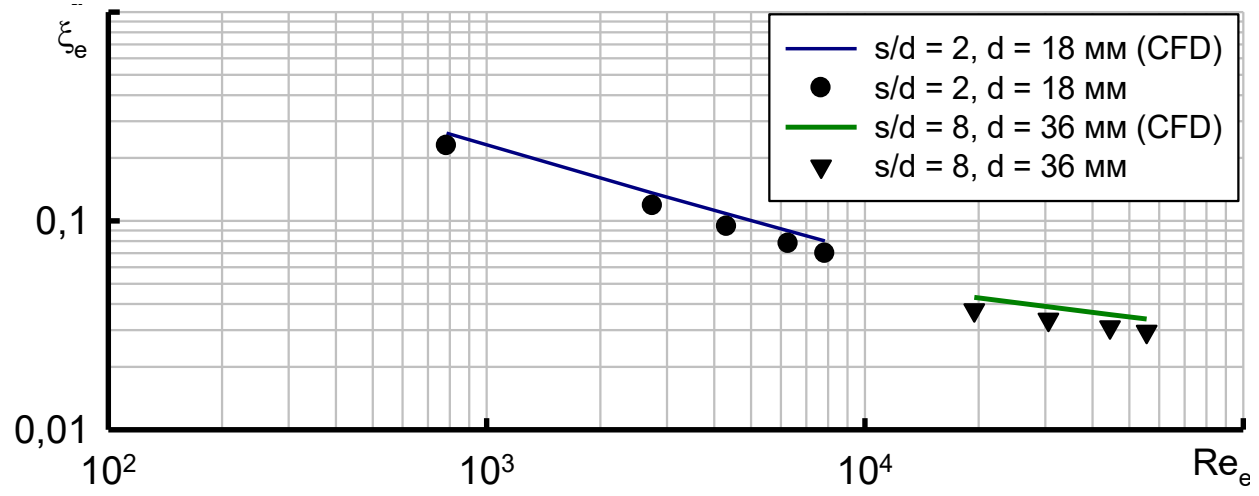

б)

Рис. 3. Верифікація результатів чисельного моделювання інтенсивності теплообміну (а) та коефіцієнта опору (б) для CFD-моделі зі скрученою стрічкою

приведених на рис. 3. даних свідчить, що CFDмодель «занижує» в середньому на $2 \%$ середньоінтегральні коефіцієнти тепловіддачі і «завищує» значення коефіцієнтів опору в середньому на 5\%.

Результати CFD-моделювання інтенсивності теплообміну і аеродинамічного опору стрічкових турбулізаторів представлено на рис. 4. Розшаровуючим параметром на графіку служить ступінь закрутки потоку $s / d$. Для порівняння на графіках також приведені розрахункові дані для гладкої циліндричної труби.

Як свідчать дані рис. 4, збільшення внутрішнього діаметра труби не впливає на інтенсивність теплообміну для всього дослідженого діапазону ступеню закрутки потоку $s / d$. Гідравлічний опір за тих же чисел Рейнольдса зменшується в межах $1 \%$ із збільшенням внутрішнього діаметра труб. При цьому порівняно 3 гладкою циліндричною трубою застосування стрічкового турбулізатора дозволяє збільшити інтенсивність теплообміну в середньому на $25 \%$ для труби з внутрішнім діаметром 18 мм. Для труб з 28 і 36 мм це значення становить 40 і $50 \%$ відповідно.

Як свідчить рис. 4, гідравлічний опір при цьому зростає на $66 \%$ для труби з внутрішнім діа- метром 18 мм. Для труб з 28 і 36 мм це значення становить 60 і 48\% відповідно.

Рис. 4 також свідчить, що збільшення ступеню закрутки потоку $s / d$ призводить до незначного зменшення інтенсивності теплообміну в усьому дослідженому діапазоні внутрішніх діаметрів труб. Це може бути пояснено зменшенням ступеню турбулентності, що генерується в потоці, та зменшенням інтенсивності перемішування рідини між ядром потоку і пристінною зоною течії. Так, у випадку труби з внутрішнім діаметром 18 мм модель $3 s / d=2$ має на $25 \%$ вищу інтенсивність теплообміну, ніж модель, у якої ступінь закрутки становить 8. Те ж саме значення інтенсифікації теплообміну спостерігається для випадку труб 3 внутрішнім діаметром 28 мм. У разі збільшення внутрішнього діаметру до 36 мм інтенсивність теплообміну моделі з $s / d=2$ вище на $35 \%$, ніж модель $3 s / d=8$.

Аналіз зміни гідравлічного опору свідчить, що при ламінарному 3 макровихрами режимі течії (спостерігається у всьому діапазоні зміни внутрішнього діаметру при $s / d=2$ ) коефіцієнт гідравлічного опору різко змінюється зі зміною числа Re. При турбулентному режимі спостерігається 

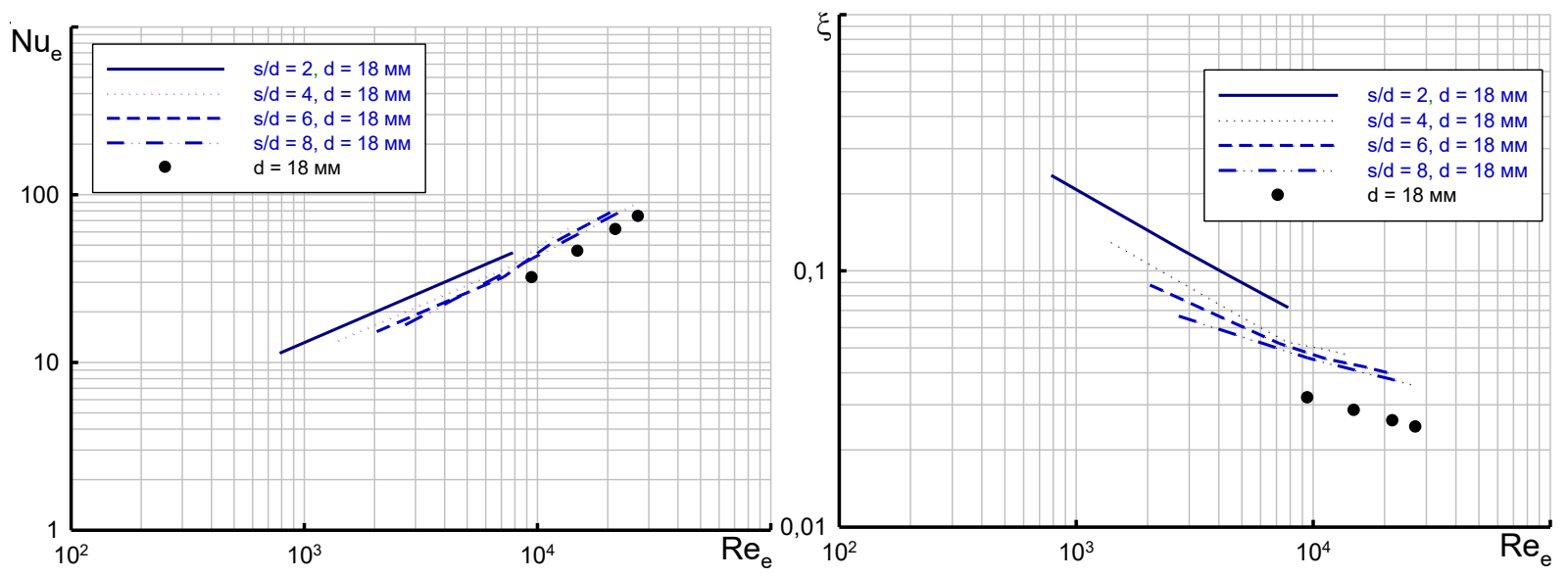

a)

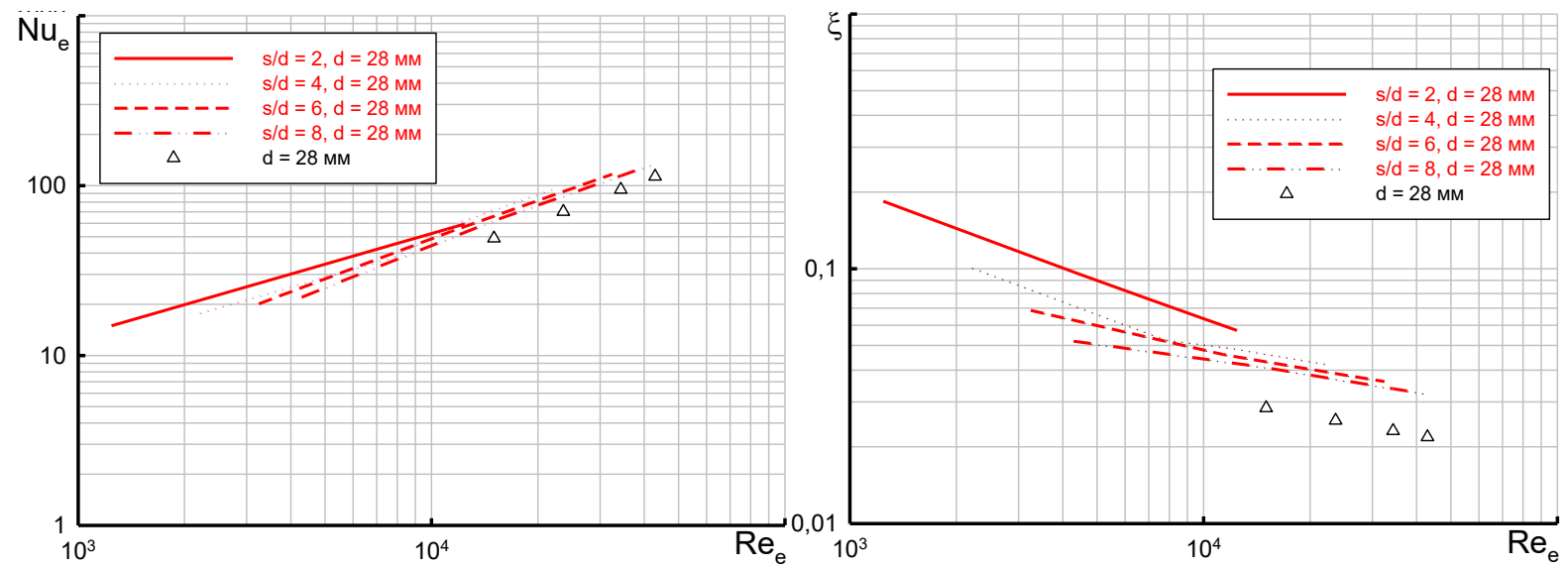

б)
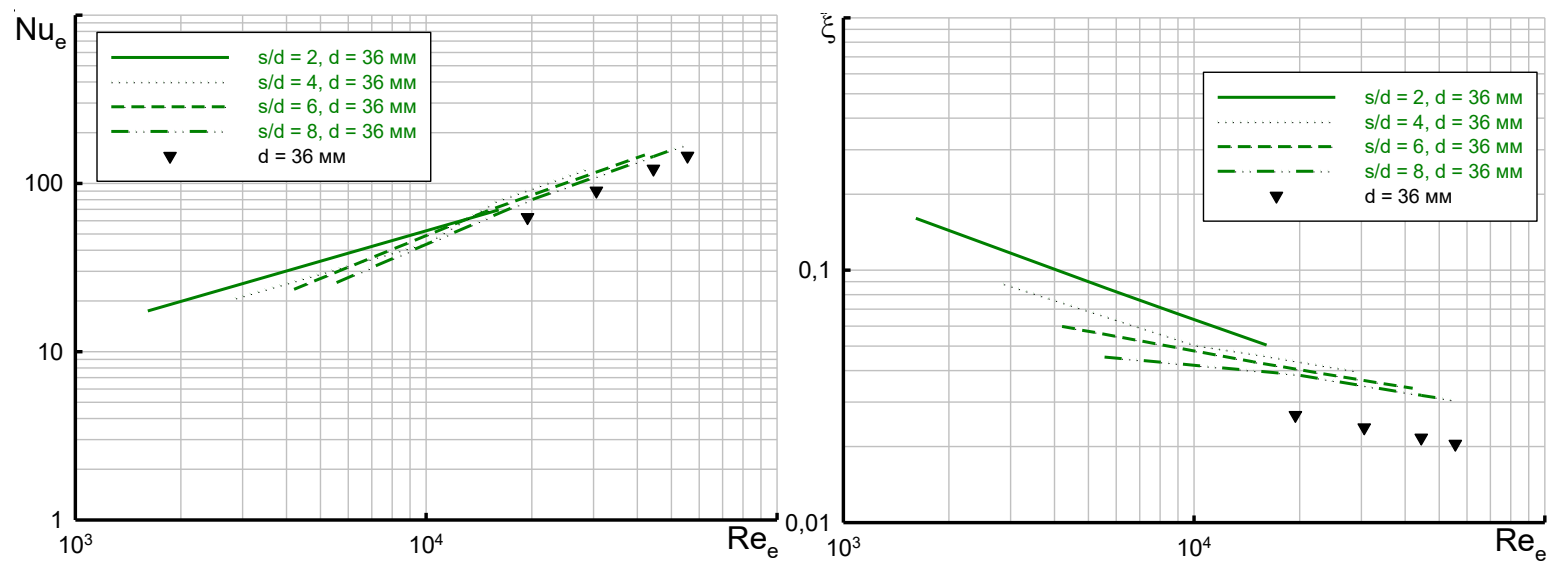

B)

Рис. 4. Результат CFD-моделювання інтенсивності теплообміну і аеродинамічного опору стрічкових турбулізаторів, що розміщені в трубах з внутрішнім діаметром 18 мм (а), 28 мм (б) та 36 мм (в)

утворення автомодельної області, для якої характерна незалежність коефіцієнту опору від числа Re. При цьому у випадку труби з внутрішнім діаметром 18 мм при $\operatorname{Re}=10^{4}$ модель $3 s / d=2$ має в 1,6 рази вищий гідравлічний опір, ніж модель, у якої ступінь закрутки становить 8. Труби з вну- трішнім діаметрами 28 і 36 мм при $\mathrm{Re}=10^{4}$ при зміні $s / d$ від 2 до 8 мають в 1,5 та 1,25 вищий гідравлічний опір.

На рис. 5 представлені розподіли частоти обертового руху потоку (velocity curl), що характеризують інтенсивність обертання вторинної течії. 


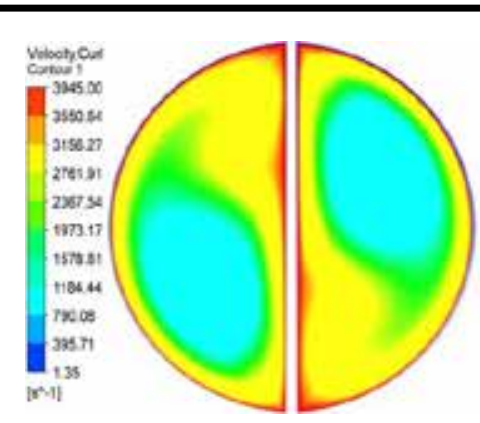

a)

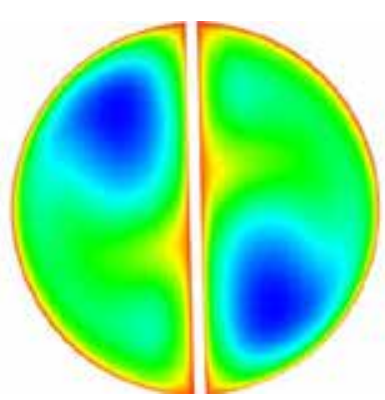

б)

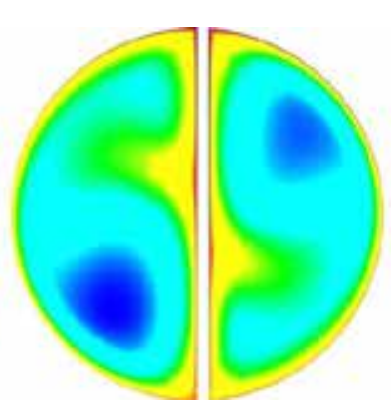

B)

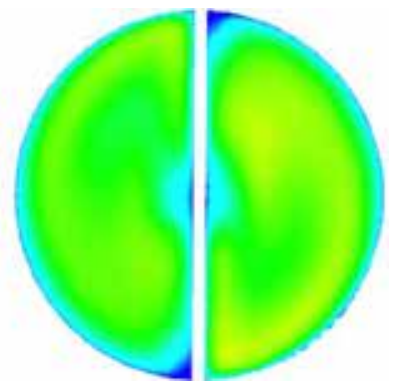

г)

Рис. 5. Результат розрахунку частоти обертання потоку в поперечному перерізі на виході 3 труби із стрічковою вставкою при $s / d=2(\mathrm{a}), s / d=4\left(\right.$ б), $s / d=6\left(\right.$ в), та $s / d=8$ (г) при $\operatorname{Re}=2 \cdot 10^{4}$

Представлений розподіл є типовим розподілом поля швидкості при турбулентній течії в трубі зі скрученої стрічкою, що отриманий в роботі [15].

Аналіз рис. 5 свідчить, що зі збільшенням ступеню закрутки потоку (зі зменшенням кількості обертів скрученої стрічки) відбувається зменшення частоти обертового руху, чим може пояснюватись зменшення інтенсивності теплообміну.

Обговорення отриманих результатів. Інтенсифікація тепловіддачі в закрученому потоці досягається за рахунок збільшення пристінної швидкості потоку і вторинних течій. Вторинні течії виникають під дією відцентрових сил і підсилюють теплообмін між ядром потоку і примежовим шаром на стінці каналу. Важливим є і той факт, що скручена стрічка збільшує поверхню теплообміну. В представленій задачі завдяки тому, що між стінкою труби і скрученою вставкою немає термічного опору, спостерігається ефект оребрення. Вставка у вигляді теплопровідності передає теплоту від стінки труби до повітряного потоку. Слід зазначити, що частка теплового потоку за рахунок ефекту оребрення не перевищує 30\% від кількості теплоти, яким обмінюються стінка труби і теплоносій шляхом тепловіддачі.

Збільшення гідравлічного опору труби зі скрученою стрічкою пов'язано із збільшенням поверхні тертя, що своєю чергою призводить до додаткових витрат енергії на створення обертального руху повітряного потоку і утворення вторинних поперечних течій.
Висновки. Проведено дослідження гідравлічного опору й інтенсивності теплообміну в круглій трубі із турбулізатором у вигляді закрученої стрічки. Напрям закручування стрічок був однаковим для усіх досліджених випадків.

Аналіз отриманих даних свідчить, що зменшення кроку закрутки спіральної стрічки $s$ призводить до збільшення кількості витків спіралі на одиницю довжини труби. Це своєю чергою призводить до зміни режиму течії і до збільшення середніх чисел Нуссельта і коефіцієнтів гідравлічного опору.

При фіксованих значеннях $s / d$ зміна внутрішнього діаметра труби не впливає ні на інтенсивність теплообміну, ні на зростання гідравлічного опору. Основним впливовим параметром, що впливає на згадані характеристики, є ступінь закрутки потоку $s / d$. Чим більший крок закрутки спіральної стрічки $s$, тим менше кількість витків спіралі і менша кривизна їі поверхні. Все це призводить до створення умов більш плавного омивання поверхні теплообміну, зменшення витрат енергії на створення обертального руху і утворення вторинних поперечних течій.

Для всіх стрічок-вставок спостерігається тенденція до збільшення інтенсивності теплообміну зі зменшенням коефіцієнту закрутки $\mathrm{i}$ зростанням числа Рейнольдса. Середні числа Нуссельта для труби із закрученої стрічкою, в середньому на $25 \%$ вище, ніж для гладкої циліндричної труби.

\section{Список літератури:}

1. Лаптев А.Г., Николаев Н.А., Башаров М.М. Методы интенсификации и моделирования тепломассообменных процессов. Учебно-справочное пособие. Москва : «Теплотехник», 2011. 335 с.

2. IRE-Polus. Визуализация потока. URL: https://www.ipgphotonics.com/ru/applications/innovatsii-inauka/vizualizatsiya-potoka. $14.03 .2021 \mathrm{p}$.

3. Скородумов А.П., Шершнев Б.Б. Теплообмен в гладкой трубе с ленточным завихрителем. URL: https://www.ansysadvantage.ru/heat-transfer-in-a-smooth-tube/. 14.03.2021 p. 
4. Белов И.А., Кудрявцев Н.А. Теплоотдача и сопротивление пакетов труб. Ленинград : Энергоатомиздат, 1987. С. 32-36.

5. Гортышев Ю.Ф., Олимпиев В.В. Теплообменные аппараты с интенсифицированным теплообменом. Казань : Изд-во КГТУ им. А.Н. Туполева, 1999. 176 с.

6. Дзюбенко Б.В., Кутепов А.М., Свириденко И.П., Федик И.И., Харитонов В.В., Холпанов Л.П. Интенсификация тепло- и массообмена в энергетике. Москва : ФГУП «ЦНИИАТОМ-ИНФОРМ», 2003. 232 с.

7. Калинин Э.К, Дрейцер Г.А., Ярко С.А. Интенсификация теплообмена в каналах. Москва : Машиностроение, 1990.

8. Мигай В.К. Повышение эффективности современных теплообменников. Ленинград : Энергия, 1980. 144 с.

9. Жукаускас А.А. Конвективный перенос в теплообменниках. Москва : Наука, 1982. 472 с.

10. Щукин В.К., Халатов А.А. Теплообмен, массообмен и гидродинамика закрученных потоков в осесимметричных каналах. Москва : Машиностроение, 1982. 200 с.

11. Shih T.-H., Liou W. W., Shabbir A., Yang Z., Zhu J. A New k- $\varepsilon$ EddyViscosity Model for High Reynolds Number Turbulent Flows - Model Development and Validation. Computers and Fluids. 1995. Vol. 24, No 3. P. 227-238.

12. Ferziger, J.H., Peric, M. Computational methods fluid dynamics. Berlin: Springer, 2001. 423 p.

13. Исаченко В.П., Осипова В.А., Сукомел А.С. Теплопередача: учебник для вузов. Москва : Энергия,1975. 488 с.

14. Чангчароэн В., Сомравысин П., Эямса-ард П., Эямса-ард С. Особенности теплообмена затухающего вихревого потока через круглую трубу с генератором вихрей с двойной закруткой в прямом и противоположном направлениях. Теплофизика и аэромеханика, 2016, том 23, № 4, С. 543-557.

15. Митрофанова О.В. Гидродинамика и теплообмен закрученных потоков в каналах ядерноэнергетических установок. Москва : «Физматлит», 2010. 290 с.

\section{Baranyuk A.V., Vorobiov M.V. SIMULATION OF FLOW AND HEAT EXCHANGE IN TUBES WITH TURBULIZERS IN THE FORM OF TWISTED TAPES}

Numerical research and construction of a numerical flow model in cylindrical tubes with a heat exchange intensifier in the form of a twisted tape using ANSYS-Fluent were carried out. The aim of the work is to study the mechanism of heat exchange intensification in the conditions of complex internal flow with the help of CFD-methods. To achieve this goal, a CFD model of flow and heat exchange was developed in cylindrical tubes with diameters of 18,28 and $36 \mathrm{~mm}$ inside which a twisted tape was placed. The degree of twisting varied from 3 to 9 into the tube: average temperature $T_{\infty}=19,3{ }^{\circ} \mathrm{C}$, pressure $P_{\infty}=0,1 \mathrm{MPa}$, degree of turbulence $T u \infty=1 \%$, velocity profile - uniform. Boundary conditions of the form $T_{w}=$ const were set on the wall. The similarity numbers were calculated from the average air velocity attributed to the circular cross section of the tube with an inner diameter $d$, which served as the determining size. The average temperature of the air flow in the tube was taken as the determining temperature. The studies were performed in the range of Reynolds numbers $R e=(1,5 \ldots 4,4) \cdot 10^{4}$.

Preliminary validation of the calculation method for cylindrical tubes shows that the model developed in the ANSYS-Fluent environment correctly reflects the essence of the processes of flow and heat exchange in a cylindrical tube and can be used to study the separation process in tubes with turbulizers. The academic license of the ANSYS Student software complex was used for modeling, which is (since 2015) absolutely free and is intended for solving introductory and educational tasks in the academic environment.

The results of CFD modeling showed that the intensification of heat transfer is achieved by increasing the near-wall flow rate and the occurrence of secondary currents that occur under the action of centrifugal forces and enhance heat transfer between the flow core and the boundary layer that develops on heat exchange surfaces. Unfortunately, no anticipatory growth of heat transfer over the growth of hydraulic resistance. The hydraulic resistance of a tube with a twisted tape increases (in comparison with a cylindrical tube) on the average in 1,35-1,55 times. This may be due to an increase in the friction surface and additional energy consumption to create the rotational motion of the coolant and the formation of secondary transverse flows.

Key words: forced convection, intensification, twisted tape, modeling, vorticity, secondary currents. 